Island Studies Journal, Vol. 5, No. 1, 2010, pp. 43-60

\title{
Folk Toponymy and Offshore Fishing Ground Names on the Dudley Peninsula, Kangaroo Island, South Australia
}

\author{
Joshua Nash \\ University of Adelaide \\ Australia \\ joshua.nash@adelaide.edu.au
}

\begin{abstract}
This paper analyses data on two aspects of unofficial place-naming or folk toponymy on the Dudley Peninsula, the eastern peninsula of Kangaroo Island, South Australia, namely (1) local unofficial toponyms, and (2) offshore fishing ground names. These place-name categories reflect naming patterns that embody specific local events, history and land use in the island's colourful past, and represent an important element of the collective memory of the area. It argues that a deeper analysis of various taxa of folk toponymy, especially in remote island locations with brief histories, can help toponymists and linguists understand broad principles involved in place-naming. Furthermore, it suggests island toponymy in Australia is an under-researched field, which deserves greater prominence in Australian place-name studies.
\end{abstract}

Keywords: Australia, islands, Kangaroo Island, naming motivation, offshore fishing ground names, toponymy, unofficial place-names

(C) 2010 - Institute of Island Studies, University of Prince Edward Island, Canada.

\section{Introduction}

Putting a linguistic turn on island studies is nothing new. Studies into isolation as a linguistic construct (Montgomery, 2000), island dialectology (e.g. St Helenian English by Schreier [2008]) and the attraction of islands to linguists for observing the development of new language systems and language change (e.g. Long, 2007) build on age-old notions of the "islands as experiments" metaphor (Spriggs, 2008). The study of island varieties of lesser-known varieties of English (e.g. Schreier et al. 2010) is presently in vogue and emphasizes the great tussle between isolation, linguistic adaptation/adaptability and the requirements for island peoples to be able to describe adequately the environment in which they live as a type of, among other things, environmental management tool (Mühlhäusler, 2003). The diachronic aspect of lexical change on islands and their ability to cope with new and challenging environmental situations has not been greatly emphasized in linguistic studies in Oceania and Australia (Mühlhäusler, 1996); nor has the importance of place-names as descriptive lexical tools been stressed greatly in island literature or linguistics. 


\section{J. Nash}

In Australia, place-name studies can be divided into two main categories. The first is descriptive and historically based, dealing mainly with large butterfly collections of (generally colonial inspired) place-names (e.g. Tent \& Slayter, 2009); while the second is primarily focused on Aboriginal place-name history and analysis. The importance and contribution of island toponymy for Australian place-name studies has not been emphasized, other than some preliminary work by Blair (2008) and Mühlhäusler (2002). Here, I argue that analysing a small set of locally used and previously undocumented place-names can contribute to island studies and Australian toponymy. I also suggest the specific importance of isolated desert islands to the study of (Australian) island toponymy.

This paper presents selected data of two taxa of the unofficial toponymy of Kangaroo Island, South Australia, obtained via fieldwork on the Dudley Peninsula, the island's easternmost peninsula. These taxa are: (1) unofficial place-names or folk toponyms; and (2) offshore fishing ground names. They constitute a major part of the unofficial naming of Kangaroo Island and the Dudley Peninsula. While I do claim that Kangaroo Island's toponymic landscape and history are unique, what is said here could be said of any isolated location and more specifically any island situation. I posit that Kangaroo Island serves to highlight some general principles of unofficial place-naming practices that are relevant to other isolated and enisled locations. The research also partially documents an aspect of Kangaroo Island's cultural history which has not been recorded in much detail. The two research questions I explore in this paper are:

- $\quad$ what are the motivations for unofficial place-naming on the Dudley Peninsula?; and

- what are the motivations for fishing ground naming around the Dudley Peninsula?

Remote and isolated islands offer linguists and toponymists rich and illustrative toponymic case studies, firstly because island people see themselves as being different to outsiders. This is reflected in the way they relate to, and talk about, the world (King \& Connell, 1999), and this creates a strong sense of self which is idiosyncratic to the particular place where they live (Péron, 2004). Secondly, and especially in remote oceanic islands, there may be little and sporadic contact with outside forces for long periods of time. The resulting isolation and seclusion of islands provides for a keener sensation of cognitive and social isolation requiring a greater reliance on the sea and an increased need for community strength and solidarity. Here, the question arises as to whether there is any significant difference in the naming of island places from mainland places. Research - as with Coates (1991), among various other studies looking at place-naming on islands - suggests that there are not. However, islands provide situations where extraneous factors are reduced and clearer conclusions can be drawn regarding the history, location and meaning of 
place-names. Small islands are manageable research settings due to their size and clear geographical demarcation. Moreover, if an island has a relatively brief (modern/Western) history, as Kangaroo Island does ${ }^{1}$, the traceability of land use, people and names makes analysis more concise and provides an ideal case study of the linguistic change in island environments. New populations have to describe and/or adapt linguistically to new and foreign environments. During this stage, it is very common for massive anthropogenic environmental change to occur.

\section{Kangaroo Island}

Kangaroo Island (henceforth KI) lies some $120 \mathrm{~km}$ south of Adelaide (see Figure 1). The Dudley Peninsula has a land area of around $650 \mathrm{~km}^{2}$ and only one settlement, Penneshaw. The name is a blend derived from combining the names of Dr. F.W. Pennefather and Flora Louisa Shaw, two South Australian dignitaries at the time of colonization. It was previously named Hog Bay by British explorer Matthew Flinders, and Anse des Sources (Cove of Springs) by French explorer Nicolas Baudin.

The South Australian Geographic Names Board has produced a gazetteer of place-names covering all of South Australia, in which KI names are included (SA Environment and Geographic Information, 1999). The overwhelming amount of KI names in this gazetteer already appear on published maps. They are in everyday use by much of the KI community. What I am concerned with here are the local and unofficial names that are not listed or positioned on maps.

\section{Locating Kangaroo Island Toponymy within Australian Toponymy}

Current theory in documenting, locating and interpreting the meaning and significance of indigenous place-names is given in Hercus et al. (2002) and Koch \& Hercus (2009). These publications have arisen out of, and on the back of, decades of research into indigenous Australian languages, where documenting indigenous toponyms initially was seen simply as a part of recording any other aspect of the lexicon. As the importance of toponymy and accurate mapping grew and became integral to Aboriginal native title land claims and the development of the notion of 'Country' vis-à-vis language and clan boundaries during the 1970s and 1980s, place-names came to be used as reliable linguistic and cultural source material for designating land ownership, location and connection to land (Sutton, 1995).

${ }^{1}$ In this paper, although there were several previous instances of Aboriginal inhabitation, only events that occurred on Kangaroo Island after European settlement are considered. 


\section{J. Nash}

Figure 1: Location of Kangaroo Island, South Australia showing the Dudley Peninsula.

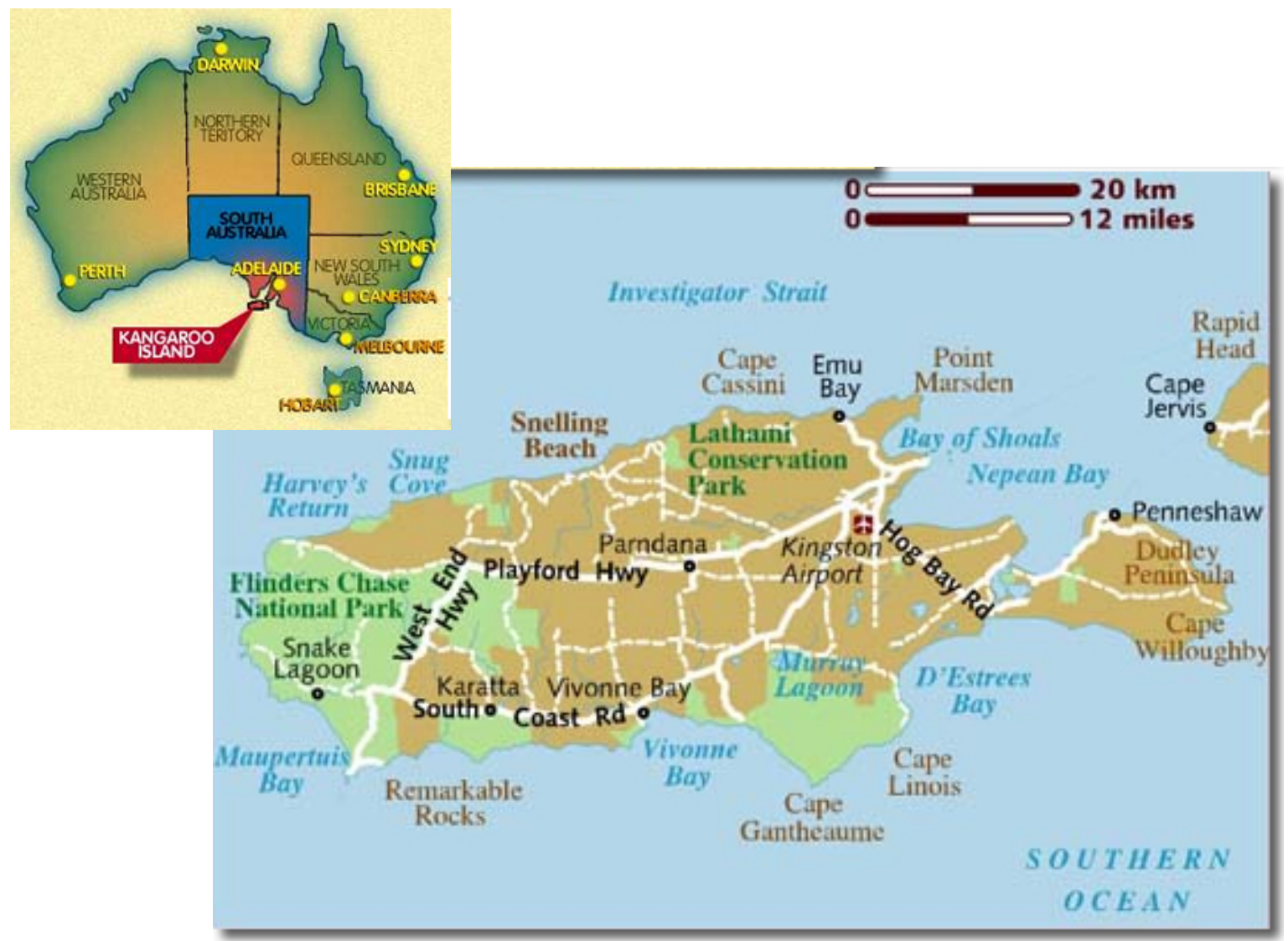

More than 500 non-English, European place-names also dot the Australian coastline. They are testament to the voyages of Dutch and French explorers in the 1600s and 1700s (Tent \& Slayter, 2009). It is in looking particularly at the French place-names in South Australia that we arrive at the history of KI, and Baudin's voyage in 1802 on the Géographe.

Apart from a preliminary analysis of Norfolk Island place-names (Mühlhäusler, 2002) and unpublished work on Lord Howe Island (Blair, 2008) - the former a territory of Australia and the latter an unincorporated area of New South Wales - more detailed accounts of primal toponymy in Australia are pending. A compilation of the place-names of KI and/or any of its counties has never been published. There seems to be a history of naming of KI fishing grounds as suggested by Capel (1977), Mensforth \& Irving (2000) and Scarce (1985). There is, however, no published toponymic account documenting the fishing culture and place-names associated with the Dudley Peninsula and the waters around Penneshaw. 


\section{Classification and Data Division}

Figure 2 presents a classification system for doing place-name research. I have presented this system elsewhere (Nash, 2009) and it has been arrived at through conducting long-term toponymic research.

Figure 2: Place-name Classification

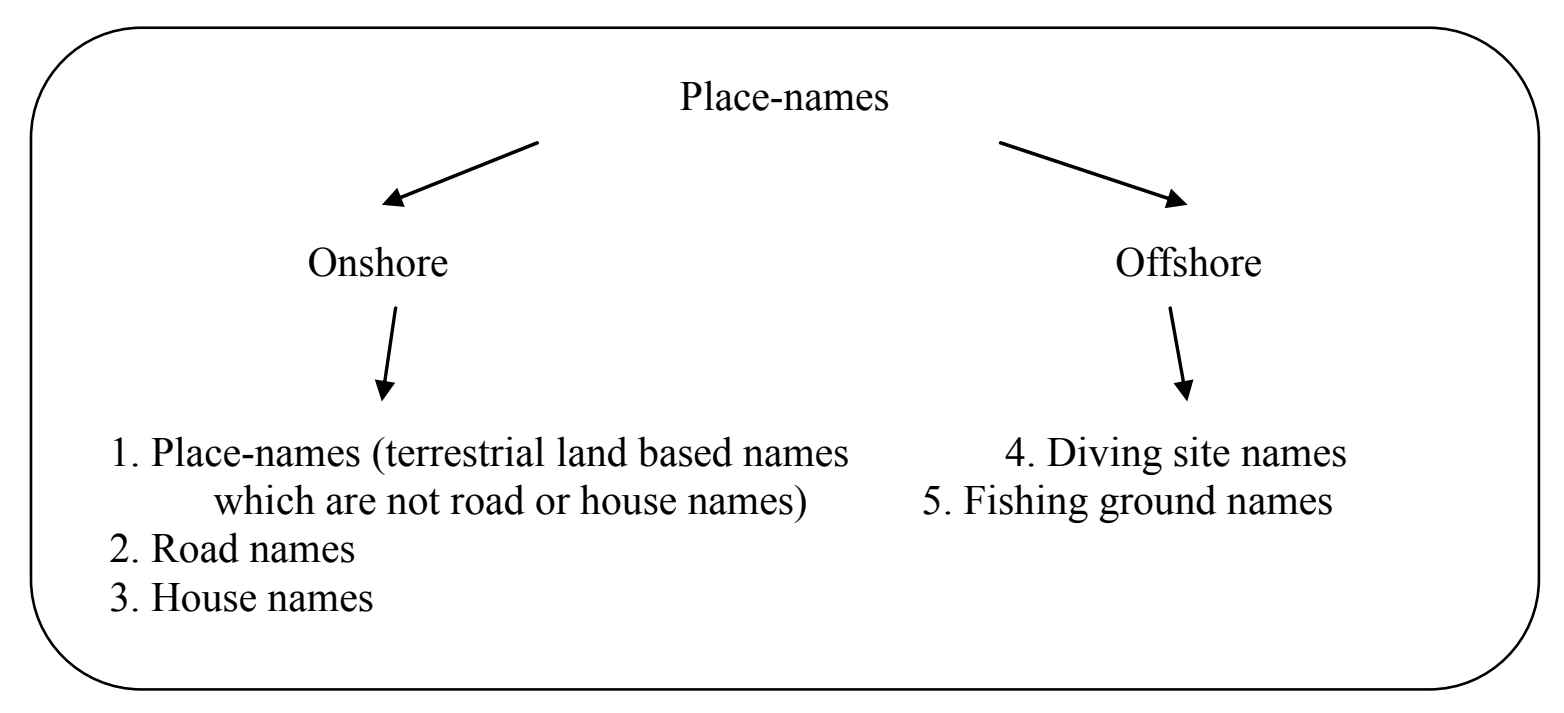

Place-names (category 1) can be divided into official and unofficial names. They can further be divided into names of hills and mountains, creeks and bays. I will employ a taxonomy for place-naming motivation developed by the Australian National Place-name Survey (Tent \& Slayter, 2009: 22-26). I am using this tool because it is the most up to date method for place-name analysis in Australia. Furthermore, since my place-name research also concerns islands, I utilize this taxonomy to ascertain whether there are any major significant differences between island and mainland/continental/non-isolated place-naming. This taxonomy is presented below in Figure 3 . The semantic components that accompany the figure are then explained in Table 1. 
Table 1: Semantic Components Explained

\begin{tabular}{|l|l|}
\hline [+DESCRIPTIVE] & reflects a characteristic of the feature or its environment \\
\hline$[+$ EMOTIVE] & reflects a subjective response by the namer to the feature \\
\hline +INHERENT] & $\begin{array}{l}\text { characteristic of the feature itself, rather than of its surrounds or } \\
\text { context } \\
\text { characteristic of the physical surrounds of the feature, rather than of } \\
\text { any event associated with the naming }\end{array}$ \\
\hline$[+$ CONTEXT] & relates to the linguistic form of the name \\
\hline$[+$ LINGUISTIC $]$ & deliberately constructed as an innovative linguistic form \\
\hline$[+$ INTENDED $]$ & $\begin{array}{l}\text { Indicates the toponym has been reapplied from another location, } \\
\text { another feature type, or another language system }\end{array}$ \\
\hline [+MOVE] & $\begin{array}{l}\text { indicates the toponym has been reapplied from an Australian } \\
\text { Indigenous language }\end{array}$ \\
\hline
\end{tabular}

\section{Methodology}

The data for this paper were collected on a 10-day fieldtrip to KI in February 2009. The fieldwork was based in and around Penneshaw, the main settlement on the Dudley Peninsula. Interviews took place on people's family farms and properties; some of the interviews took place in people's work situations where they use these colloquial toponyms. Collecting offshore fishing ground names involved interviewing four fishers exploring the name, history, usage and possibly eliciting the location and bearing information of the fishing grounds. All respondents were born on KI and had lived most of their life on the island. They were all well respected and well known within the community. The majority were retirees while two older non-retired males still maintain family owned farming properties. All data have come from people who have been involved in farming well-established family estates allotments and/or were involved in providing fish, in either large or small quantities, to the local tourism industry. Two fishers had been professional while the other two were recreational. Data from one elderly female informant has been included in the sample. I claim this sample appears as an indicative yet reliable example of the collective place-name memory of older members of the Dudley Peninsula community. 
Folk Toponymy and Offshore Fishing Ground Names on Kangaroo Island

Figure 3: Taxonomy of Australian Toponym Specifics (source: Tent \& Slayter, 2009: 25).

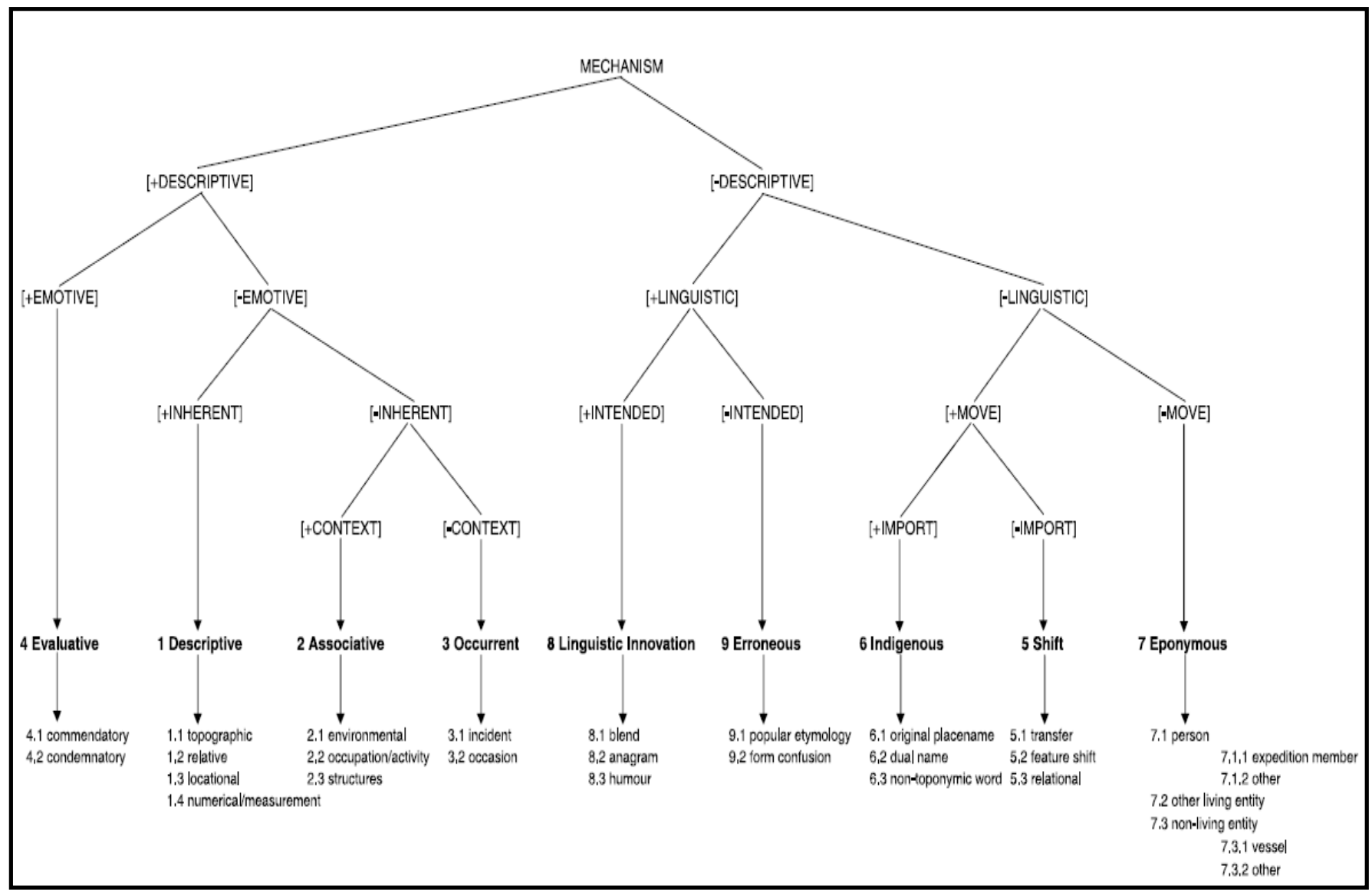

\section{Results}

Through interviewing informants it became clear that these names have obviously arisen in relation to particular properties, environments, people and activities. The names appear to have evolved through a combination of farmers needing to know and identify locations for agricultural activity and as a way for local people, and particularly children, to remember local legends and the places they used to play. These names are not recorded on private estate maps nor are they present on official maps. (In this dataset the exceptions are 'Charlie's Gulch' and 'Rifle Range Gully' which are more widely known.) They are not alternatives to official names as such; but are small scale means for local orientation and pragmatic and historical landscape description. 


\section{J. Nash}

Table 1 presents a selection of 15 Dudley Peninsula folk toponyms and their purported histories and etymologies according to my informants. It also presents a descriptive analysis using the Tent \& Slayter (2009) taxonomy. I must emphasize that these place-name histories are being presented as close and faithful as possible to informants' accounts. In doing so, I am reminded of Mühlhäusler's (2006: 110) statement that:

Memories are not factual records of events but socially negotiated. Etymologizing for any language is a mixture of factual information and socially acceptable accounts.

Table 1: Dudley Peninsula folk toponyms and histories

\begin{tabular}{|c|c|c|}
\hline TOPONYM & HISTORY & $\begin{array}{c}\text { ANALYSIS (based on Tent } \\
\text { \& Slayter, 2009) }\end{array}$ \\
\hline 1. Big Duck & $\begin{array}{l}\text { A place in the southwestern corner of } \\
\text { Pelican Lagoon near the Muston turnoff. } \\
\text { The owners' daughter brought her } \\
\text { English husband to the area; when he } \\
\text { saw the pelicans, he exclaimed he was } \\
\text { surprised to see such 'big ducks'. }\end{array}$ & $\begin{array}{l}\text { [+ DESCRIPTIVE] } \\
{[- \text { EMOTIVE] }} \\
{[- \text { INHERENT] }} \\
{[+ \text { CONTEXT] }} \\
2 \text { Associative } \\
\text { 2.1 environmental }\end{array}$ \\
\hline 2. Big Prickly & $\begin{array}{l}\text { Cf. Little Prickly on the same property. } \\
\text { A location on a property around Porky } \\
\text { Flat in the centre of Dudley Peninsula. } \\
\text { Named as such because there used to be } \\
\text { large prickle bushes in the area. }\end{array}$ & $\begin{array}{l}\text { [+ DESCRIPTIVE] } \\
{[- \text { EMOTIVE] }} \\
\text { [+ INHERENT] } \\
1 \text { Descriptive } \\
1.1 \text { topographic }\end{array}$ \\
\hline $\begin{array}{l}\text { 3. Charlie's } \\
\text { Gulch }\end{array}$ & $\begin{array}{l}\text { Named after Charles Bates, who used to } \\
\text { haul a crayfish boat along the land from } \\
\text { the mouth of the creek at Bore Beach on } \\
\text { the south coast of the Dudley Peninsula, } \\
\text { a beach so named because of the } \\
\text { petroleum bore set up there around } \\
1910 \text {. He would then put the boat out to } \\
\text { sea to go crayfishing down at a place } \\
\text { which came to be known as Charlie's } \\
\text { Gulch, a deep fjord with large swells } \\
\text { which thrusts into the cliffs. He would } \\
\text { take dray-loads of his catch into } \\
\text { Penneshaw. }\end{array}$ & $\begin{array}{l}\text { [- DESCRIPTIVE] } \\
\text { [- LINGUISTIC] } \\
\text { [- MOVE] } \\
7 \text { Eponymous } \\
7.1 \text { person }\end{array}$ \\
\hline
\end{tabular}


Folk Toponymy and Offshore Fishing Ground Names on Kangaroo Island

\begin{tabular}{|c|c|c|c|}
\hline & $\begin{array}{l}\text { Dead Dog } \\
\text { Gate }\end{array}$ & $\begin{array}{l}\text { A name on several properties on the } \\
\text { Dudley Peninsula. Typically named } \\
\text { because a dog came to grief here, after } \\
\text { becoming snagged on a fence gate. }\end{array}$ & $\begin{array}{l}\text { [+ DESCRIPTIVE] } \\
\text { [- EMOTIVE] } \\
\text { [- INHERENT] } \\
\text { [- CONTEXT] } \\
2 \text { Occurrent } \\
2.1 \text { incident }\end{array}$ \\
\hline & $\begin{array}{l}\text { Deadwood } \\
\text { Hill }\end{array}$ & $\begin{array}{l}\text { Another name with several occurrences } \\
\text { on different properties. Generally named } \\
\text { after the appearance of old, dry, grey } \\
\text { wood from felled or fallen eucalypts on } \\
\text { top of a property's undulating terrain. }\end{array}$ & $\begin{array}{l}\text { [+ DESCRIPTIVE] } \\
{[- \text { EMOTIVE] }} \\
{[- \text { INHERENT] }} \\
\text { [+ CONTEXT] } \\
2 \text { Associative } \\
2.1 \text { environmental }\end{array}$ \\
\hline & Four Square & $\begin{array}{l}\text { A property on the Willson River Road } \\
\text { on the left side heading south. The } \\
\text { boundary lines in the area run like that } \\
\text { and appear like a square. }\end{array}$ & $\begin{array}{l}\text { [+ DESCRIPTIVE] } \\
\text { [- EMOTIVE] } \\
\text { [- INHERENT] } \\
\text { [+ CONTEXT] } \\
2 \text { Associative } \\
2.1 \text { environmental }\end{array}$ \\
\hline & $\begin{array}{l}\text { Jack's } \\
\text { Paddock }\end{array}$ & $\begin{array}{l}\text { A well-known paddock on the Willson } \\
\text { River property where as legend goes } \\
\text { Jack, the son of an old farmer, had his } \\
\text { first time with a girl. }\end{array}$ & $\begin{array}{l}\text { [- DESCRIPTIVE] } \\
\text { [- LINGUISTIC] } \\
\text { [- MOVE] } \\
7 \text { Eponymous } \\
7.1 \text { person } \\
\end{array}$ \\
\hline & $\begin{array}{l}\text { The Miner's } \\
\text { Arms }\end{array}$ & $\begin{array}{l}\text { There used to be a gold mine on the top } \\
\text { of Bald Hill on the left side of the Cape } \\
\text { Willoughby Road. Amongst the old gum } \\
\text { trees there used to be some old buildings } \\
\text { which were known as The Miner's } \\
\text { Arms. The buildings are gone but the } \\
\text { trees remain. }\end{array}$ & $\begin{array}{l}\text { [+ DESCRIPTIVE] } \\
\text { [- EMOTIVE] } \\
\text { [- INHERENT] } \\
\text { [+ CONTEXT] } \\
2 \text { Associative } \\
2.1 \text { environmental }\end{array}$ \\
\hline & $\begin{array}{l}\text { Moan a' } \\
\text { Tree }\end{array}$ & $\begin{array}{l}\text { A large eucalypt on the Willson River } \\
\text { Road with two possible etymologies: (1) } \\
\text { once some people were walking past the } \\
\text { tree while moaning and complaining } \\
\text { about the walk they had just been on. } \\
\text { This 'moaning' and the location of } \\
\text { where it happened were remembered; } \\
\text { and (2) the sound the wind makes as it } \\
\text { blows through this particular tree sounds } \\
\text { like moaning. Used commonly as a } \\
\text { reference point. }\end{array}$ & $\begin{array}{l}\text { [+ DESCRIPTIVE] } \\
\text { [- EMOTIVE] } \\
\text { [+ INHERENT] } \\
1 \text { Descriptive } \\
1.1 \text { topographic }\end{array}$ \\
\hline
\end{tabular}




\section{J. Nash}

\begin{tabular}{|c|c|c|}
\hline 10. Pirkey’s & $\begin{array}{l}\text { A house name and general name for the } \\
\text { region on the eastern end of The Lane in } \\
\text { Penneshaw. }\end{array}$ & $\begin{array}{l}\text { [- DESCRIPTIVE] } \\
\text { [- LINGUISTIC] } \\
\text { [- MOVE] } \\
7 \text { Eponymous } \\
7.1 \text { person }\end{array}$ \\
\hline $\begin{array}{l}\text { 11. Rifle Range } \\
\text { Gully }\end{array}$ & $\begin{array}{l}\text { A very steep gully around the } \\
\text { Penneshaw area named such because } \\
\text { there used to be a rifle range there. } \\
\text { Locals also know this gully as Morepork } \\
\text { Gully, the local name of a native owl } \\
\text { found in the area. Rifle Range Gully } \\
\text { leads onto Blue Gum Gully. }\end{array}$ & $\begin{array}{l}+ \text { DESCRIPTIVE] } \\
\text { [- EMOTIVE] } \\
\text { [- INHERENT] } \\
\text { [- CONTEXT] } \\
2 \text { Occurrent } \\
2.2 \text { occupation/activity }\end{array}$ \\
\hline $\begin{array}{c}\text { 12. Streaky } \\
\text { Grass }\end{array}$ & $\begin{array}{l}\text { An area on the Trethewey property in } \\
\text { the middle of the Dudley Peninsula. One } \\
\text { day two brothers were put to work on } \\
\text { sowing grass seeds by hand. As it was a } \\
\text { hard job, the boys walked apart. When } \\
\text { the rains came, their shoddy } \\
\text { workmanship, which resulted in streaks } \\
\text { of grass across the paddock rather than } \\
\text { evenly distributed grass, was revealed. }\end{array}$ & $\begin{array}{l}\text { [+ DESCRIPTIVE] } \\
\text { [- EMOTIVE] } \\
\text { [+ INHERENT] } \\
1 \text { Descriptive } \\
1.1 \text { topographic }\end{array}$ \\
\hline $\begin{array}{l}\text { 13. The } \\
\text { Triangle }\end{array}$ & $\begin{array}{l}\text { Two adjacent titles on the Willson River } \\
\text { Road, not far from Four Square (see \#6), } \\
\text { which appear like a triangle to the eye. }\end{array}$ & $\begin{array}{l}\text { [+ DESCRIPTIVE] } \\
{[- \text { EMOTIVE] }} \\
\text { [- INHERENT] } \\
\text { [+ CONTEXT] } \\
2 \text { Associative } \\
\text { 2.1 environmental }\end{array}$ \\
\hline $\begin{array}{l}\text { 14. Tiger's } \\
\text { Cairn }\end{array}$ & $\begin{array}{l}\text { A cairn, a mound of rough stones built } \\
\text { as a memorial or landmark, named by } \\
\text { Tiger Simpson, which looks out across } \\
\text { Pelican Lagoon just up from YMCA } \\
\text { Corner. }\end{array}$ & $\begin{array}{l}\text { [- DESCRIPTIVE] } \\
\text { [- LINGUISTIC] } \\
\text { [- MOVE] } \\
7 \text { Eponymous } \\
7.1 \text { person }\end{array}$ \\
\hline $\begin{array}{l}\text { 15. Tiger's } \\
\text { Tooth }\end{array}$ & $\begin{array}{l}\text { A } 300-400 \text { acre piece of land owned by } \\
\text { Tiger Simpson for many years at Cape } \\
\text { Hart. Rumour has it that one of Tiger's } \\
\text { teeth was found there. }\end{array}$ & $\begin{array}{l}\text { [- DESCRIPTIVE] } \\
\text { [- LINGUISTIC] } \\
\text { [- MOVE] } \\
7 \text { Eponymous } \\
7.1 \text { person }\end{array}$ \\
\hline
\end{tabular}


Of these 15 place-names, three (20\%) are classified according to a topographical feature (1.1 topographic), five (33.3\%) are classified according to an environmental context (2.1 environmental), five (33.3\%) are named eponymously (7.1 eponymous), one $(6.7 \%)$ is named based on an associative event (2.2 occupation/activity) and one (6.7\%) is the result of an incident $(2.1$ incident). Two thirds $(66.7 \%)$ of these names are [+DESCRIPTIVE] while $33.3 \%$ are [-DESCRIPTIVE].

Table 2 presents a selection of 10 Dudley Peninsula offshore fishing ground names and their histories. To the best of my knowledge, no map of these names has yet been produced.

Table 2: Dudley Peninsula offshore fishing ground names and histories

\begin{tabular}{|c|c|c|}
\hline $\begin{array}{l}\text { FISHING } \\
\text { GROUND NAME }\end{array}$ & HISTORY & $\begin{array}{l}\text { ANALYSIS (based on } \\
\text { Tent \& Slayter 2009) }\end{array}$ \\
\hline 1. Ada's & $\begin{array}{l}\text { Named after the fishing boat } A d a \text { which was } \\
\text { much used for fishing in the area. The } A d a \\
\text { came to KI in the } 1920 \text { s. It was named by locals } \\
\text { and the name just stuck. }\end{array}$ & $\begin{array}{l}\text { [- DESCRIPTIVE] } \\
\text { [- LINGUISTIC] } \\
\text { [- MOVE] } \\
7 \text { Eponymous } \\
7.3 \text { non-living entity } \\
7.3 .1 \text { vessel }\end{array}$ \\
\hline 2. Between the Tits & $\begin{array}{l}\text { This fishing ground uses the space in between } \\
\text { 'The Tits' (a very old local place-name which } \\
\text { describes the undulating landscape in the area) } \\
\text { in lining up the ground. }\end{array}$ & $\begin{array}{l}\text { [+ DESCRIPTIVE] } \\
\text { [- EMOTIVE] } \\
\text { [+ INHERENT] } \\
1 \text { Descriptive } \\
1.1 \text { topographic }\end{array}$ \\
\hline 3. Burnt Out House & $\begin{array}{l}\text { This house is used as a mark for several } \\
\text { people's fishing grounds in the American Beach } \\
\text { area. It was Sander's house. He was a } \\
\text { gentleman who took up land in that area. He } \\
\text { built a house and it used to just sit there with } \\
\text { only walls and nothing else for many years. } \\
\text { Now people live in it. It is about } 500 \mathrm{~m} \text { out. }\end{array}$ & $\begin{array}{l}\text { [+ DESCRIPTIVE] } \\
\text { [- EMOTIVE] } \\
{[- \text { INHERENT] }} \\
2 \text { Associative } \\
2.3 \text { structures }\end{array}$ \\
\hline 4. Crofton's Patch & $\begin{array}{l}\text { Crofton was a manager of one of the wineries. } \\
\text { He had a boat called the Kelvin. Crofton } \\
\text { showed it to Nils' father, who then named it } \\
\text { Crofton's Patch. It was named around } 1920 \text {. }\end{array}$ & $\begin{array}{l}\text { [- DESCRIPTIVE] } \\
\text { [- LINGUISTIC] } \\
\text { [- MOVE] } \\
7 \text { Eponymous } \\
7.1 \text { person }\end{array}$ \\
\hline
\end{tabular}


J. Nash

\begin{tabular}{|c|c|c|}
\hline 5. Gillfillan's & $\begin{array}{l}\text { A whiting ground, some } 2 \mathrm{~km} \text { off the Gillfillan } \\
\text { property at Antechamber Bay. There is an old } \\
\text { house on the property and you know you are in } \\
\text { this ground when you are a little distance off } \\
\text { and the front door on the house is straight } \\
\text { ahead. You drop the lines between the inside } \\
\text { and outside weedlines in the ocean and there is } \\
\text { around } 1 \mathrm{~km} \text { between them. }\end{array}$ & $\begin{array}{l}\text { [- DESCRIPTIVE] } \\
\text { [- LINGUISTIC] } \\
\text { [- MOVE] } \\
7 \text { Eponymous } \\
7.1 \text { person }\end{array}$ \\
\hline $\begin{array}{l}\text { 6. Halfwindow } \\
\text { Patch }\end{array}$ & $\begin{array}{l}\text { A patch found by starting from Christmas Cove } \\
\text { and running out until in line with the house on } \\
\text { Walkers Road, the end house nearest the sea. } \\
\text { From there get square on with the house and go } \\
\text { straight out until you see half the window on } \\
\text { the house. When you can only see half the } \\
\text { window, then you are in the right spot. It is } \\
\text { about } 90 \mathrm{~m} \text { from the shore. }\end{array}$ & $\begin{array}{l}\text { [+ DESCRIPTIVE] } \\
\text { [- EMOTIVE] } \\
\text { [- INHERENT] } \\
2 \text { Associative } \\
2.3 \text { structures }\end{array}$ \\
\hline 7. No Reason & $\begin{array}{l}\text { Jeff stopped the boat one day when he was out } \\
\text { with Shorty, put the anchor down and people } \\
\text { asked, "Why did you stop the boat?" and Jeff } \\
\text { said, "No reason". Turns out to be one of the } \\
\text { best fishing grounds in the area and it is still } \\
\text { used today. Was named some } 20 \text { years ago. It is } \\
\text { about } 500 \text { m out. }\end{array}$ & $\begin{array}{l}\text { (1) } \\
\text { [- DESCRIPTIVE] } \\
\text { [+ EMOTIVE] } \\
\text { [+ INTENDED] } \\
\text { 8 Linguistic innovation } \\
\text { 8.3 humour } \\
\text { (2) } \\
\text { [- DESCRIPTIVE] } \\
\text { [+ LINGUISTIC] } \\
\text { [- INTENDED] } \\
9 \text { Erroneous } \\
\text { 9.1 Popular etymology }\end{array}$ \\
\hline 8. Perce's Patch & $\begin{array}{l}\text { Named after Percival Clarke. As one local } \\
\text { narrates: "He was semi-retired and had a little } \\
\text { cutter and every day he would row along to this } \\
\text { particular location where he would fish. He } \\
\text { would catch quite a lot of whiting and sell them } \\
\text { to the guesthouses. He would always fish in the } \\
\text { same place and it became known to us as } \\
\text { Perce's Patch". }\end{array}$ & $\begin{array}{l}\text { [- DESCRIPTIVE] } \\
\text { [- LINGUISTIC] } \\
\text { [- MOVE] } \\
7 \text { Eponymous } \\
7.1 \text { person }\end{array}$ \\
\hline 9. Swanny's Patch & $\begin{array}{l}\text { This fishing ground was first found by Nils' } \\
\text { grandfather in } 1890 \text {. He showed the mark to } \\
\text { Nils' father, who then showed it to Nils.. It is } \\
\text { about } 2.4 \mathrm{~km} \text { out. Another fisher calls it } \\
\text { 'Outside Willson's'. }\end{array}$ & $\begin{array}{l}\text { [- DESCRIPTIVE] } \\
\text { [- LINGUISTIC] } \\
\text { [- MOVE] } \\
7 \text { Eponymous } \\
7.1 \text { person }\end{array}$ \\
\hline
\end{tabular}


Folk Toponymy and Offshore Fishing Ground Names on Kangaroo Island

\begin{tabular}{|l|l|l|}
\hline 10. T.O.'s Hole & Thomas Owen Willson, T.O., was a legend & [- DESCRIPTIVE] \\
& around the place. Shorty was with him and his & [- LINGUISTIC] \\
& son K.P. Willson in American Beach. For no & [-MOVE] \\
& reason, T.O., who was quite a stern and & 7 Eponymous \\
demanding man and not a keen fisher but just & 7.1 person \\
& happened to be in the boat on that day, insisted & \\
& that the anchor be dropped there and they & \\
& started catching fish. It was named around 30 & \\
& years ago and it is a couple of miles offshore. & \\
\hline
\end{tabular}

Of these 10 fishing ground names, five (50\%) are named eponymously after people (7.1 eponymous), two (20\%) names are associated with a manufactured structure or feature, one $(10 \%)$ is topographical (1.1 topographic), one $(10 \%)$ is eponymous and named after a boat (7.3.1 vessel) and one (10\%) is either humorous (8.3 humour) or erroneous (9.1 popular etymology). Thirty percent of these names are descriptive [+DESCRIPTIVE] while $70 \%$ are non-descriptive [-DESCRIPTIVE].

For the combined set of 25 names, 13 are [+DESCRIPTIVE] and 12 are [-DESCRIPTIVE]. The [-EMOTIVE] element is common to all (100\%) 13 [+DESCRIPTIVE] names. Of these 12 [-DESCRIPTIVE] names, 11 are [-LINGUISTIC], with all 11 [-LINGUISTIC] names being eponymous.

\section{Discussion}

For the 15 unofficial place-names, the results demonstrate that, of the nine classifications of the toponym taxonomy, only three divisions appear in the data. The high percentage of descriptive and environmental names suggests that emotional and evaluative naming common to exploratory and colonial naming is not a feature of these unofficial place-names. All the non-descriptive names are eponymous names. This implies that non-descriptive names on the Dudley Peninsula are primarily employed to commemorate people and have not come about as deliberate linguistic enterprising. According to the taxonomy, this indicates that linguistic innovation, name shift and indigenous and erroneous naming do not play a significant role in non-descriptive naming in unofficial names. Whether this is unique to KI, or indeed other small islands with their particular inhabitants with quintessential idiosyncrasies and personalities, has not been convincingly shown here. 


\section{J. Nash}

What I do propose, however, with the case of $\mathrm{KI}$ is that there are patterns which have emerged suggesting remoteness, acute localization of human history and the deposition of a collective memory into the place-name lexicon of a select group of people. These factors are often present in small island environments and particularly those where there has been a relatively brief modern history of human inhabitation and where forced environmental and linguistic adaptation has occurred. In the set of fishing ground names, an additional classification is introduced into the analysis from the toponym taxonomy: [+LINGUISTIC]. This feature indicates that such names have evolved from, for example, linguistic engineering in the form of blends or through erroneous means such as form confusion. Such a feature contrasts with [-LINGUISTIC], which demonstrates how names evolve in non-linguistic patterns through, for example, shift, importing old names or eponymy. Although this only arises in one name, it puts forward the possibility that there is more linguistic engineering and innovation in fishing culture naming than in terrestrial based naming; naming fishing grounds is a humorous, fun and potentially confusing activity which has become part of the cultural history of the Dudley Peninsula. This is possibly due to the insider nature of fishing and also because this element of naming is exclusively the realm of the male members of the community. Two offshore names in the data set exist that are associated with human-made terrestrial structures. This clearly describes how naming fishing grounds is also linked to the (human-made) environmental features used in locating them. These places can almost be conceived as 'no places': they are difficult to locate physically; they are ephemeral yet often perceivable in terms of their land-based reference points; and they are culturally not immediate or apparent - they are very private tools used by a select group of a remote community. Fishing grounds also appear to be eponymous, commemorating boats that plied the sea in these areas. The particularity of fishing ground naming to island situations has not necessarily been shown here. Capel (1977), in describing non-island situations in South Australia, also arrived at similar categories and results.

The data set as a whole shows an almost equal distribution between descriptive and non-descriptive names. There are no instances of emotive naming reflecting a subjective response to the feature or landform. Emotive naming is a common practice in official naming on KI. Some examples are 'Snug Cove', a positive name denoting the snugness of a small cove beach on the north coast of the Island, and 'False Cape', a negative name describing either the suspected location or the lack of a particular cape on the southern coast of the Dudley Peninsula. This implies that unofficial place-naming is less interpretive, evaluative or emotionally driven than official naming and names that are in more common usage. 
Folk Toponymy and Offshore Fishing Ground Names on Kangaroo Island

\section{Motivations for Place-naming}

Returning to my first research question, the motivations for the creation of unofficial place-names on the Dudley Peninsula appear to be mainly two: for orientation purposes, and to remember people. Dudley place-names form a local cultural map that remembers specific histories, stories and events linked explicitly to the Dudley's past.

My second research question concerned offshore fishing ground names. In addition to the above two points, this taxon introduces motivation based on linguistic criteria and what appears to be an important aspect of unofficial naming: humour and erroneous or popular coinages. Whether or not fishers give out precise names and locations of places while always keeping in mind their own competitive advantage is also worth considering; it is noteworthy that this characteristic of privacy and economy of names and places produces and encourages this humorous approach to naming.

For the semantic domain of naming motivation, Tent and Slayter's taxonomy shows itself to be a reasonable tool. It is still not clear as to the extent this taxonomy is able to deal with morphosyntactic and phonological elements of toponym analysis. This taxonomy also does not analyse the pragmatic component of the use and function of place-names within a specific community. Incorporating such elements into a toponymic taxonomy is important to further understanding the relationship between language, place and people. Employing a taxonomy emphasizing these linguistic and ethnographic levels may also be useful in describing how place-naming on islands is more or less idiosyncratic or more generally how island place-naming differs from continental place-naming.

This paper forms a minor part of a comparative longitudinal study into primal naming on Norfolk Island, a territory of Australia in the Southwest Pacific, and KI. In this project, one of my theoretical foci is to utilise and refine several toponym taxonomies and classification systems in order to arrive at a clearer and more comprehensive analytical tool for classifying Australian place-names and place-names in general. A suggestion for a taxonomy of place-naming in Australia is given by Walsh (2002:46), who argues that relevant information about a place-name should include at least the following:

- phonological form/graphic form

- location/feature

- 'story'

- $\quad$ semantic content

- ownership 
J. Nash

\section{Conclusion}

I conclude by proposing an alternate place-name classification system incorporating this semantic taxonomy with more detailed linguistic analysis. This has arisen out of my research on KI and Norfolk Island. It is also apparent that there exists a lacking of adequate descriptive tools in linguistics, ethnography and other disciplines relevant to toponymy to analyze place-names and their broader cultural dimensions and implications. I suggest any detailed study of place-names should incorporate the following linguistic levels:

- Location

- History and etymology

- Orthography/spelling variations

- Phonology

- Morphosyntax

- Semantics (utilizing the Tent \& Slayter taxonomy)

- Pragmatics and place-name usage

The specificity of islands and the traceable histories of place-names in island environments with brief histories such as Kangaroo Island provide an appropriate testing ground for more refined toponymic analysis and a greater understanding of the uniqueness, if any, of researching island toponymy.

\section{References}

Blair, D. (2008) Placenames on Lord Howe Island, unpublished manuscript.

Capel, D. (1977) Dave Capel's 50 Favourite Offshore Fishing Spots, Adelaide, Advanced Marketing.

Coates, R. (1991) The Place-names of Hayling Island, Hampshire, revised manuscript, www.uwe.ac.uk/hlss/llas/staff_coates r h hayling.doc.

Hercus, L., Hodges, F. and Simpson (eds.) (2002) The Land is a Map: Placenames of Indigenous Origin in Australia, Canberra, Pandanus Press and Pacific Linguistics.

King, R. and Connell, J. (eds.) (1999) Small Worlds, Global Lives: Islands and Migration, London, Pinter.

Koch, H \& Hercus, L. (eds.) (2009) Aboriginal Placenames: Naming and Re-naming the Australian Landscape, Aboriginal History Monograph No. 19, Canberra, Aboriginal History Inc. and ANU E-Press. 
Folk Toponymy and Offshore Fishing Ground Names on Kangaroo Island

Long, D. (2007) 'When Islands create Languages or, Why do Language Research with Bonin (Ogasawara) Islanders?', Shima: The International Journal of Research into Island Cultures, Vol. 1, No. 1, pp. 15-27.

Mensforth, S. and Irving, G. (2000) How to Fish KI, North Haven, South Australia, Fishing World.

Montgomery, M. (2000) 'Isolation as a Linguistic Construct', Southern Journal of Linguistics, Vol. 24, No. 1, pp. 25-36.

Mühlhäusler, P. (1996) Linguistic Ecology, London, Routledge.

Mühlhäusler, P. (2002) 'Changing Names for a Changing Landscape: The Case of Norfolk Island’, English World-wide, Vol. 23, No. 1, pp. 59-91.

Mühlhäusler, P. (2003) Language of Environment: Environment of Language, London, Battlebridge.

Mühlhäusler, P. (2006) 'The Norf'k Language as a Memory of Norfolk's Cultural and Natural Environment' in H. Johnson (ed.) Refereed Papers from the 2nd International Small Island Cultures Conference, Sydney, Small Island Cultures Research Initiative, pp. 104-111.

Nash, J. (2009) 'Naming the Sea: Offshore Fishing Grounds as Placenames on Norfolk Island and Pitcairn Island', SHIMA: The International Journal of Research into Island Cultures, Vol. 3, No. 2, pp. 118-131.

Péron, F. (2004) 'The Contemporary Lure of the Island', Tijdschrift voor Economische en Sociale Geografie, Vol. 95, No. 3, pp. 326-339.

SA Environment and Geographic Information (1999) South Australia State Gazetteer, Adelaide SA, Environment and Geographic Information.

Scarce, G. (1985) A Cruising Guide to Historic Gulf Ports, Volume 2: Investigator Strait and Kangaroo Island, Hawthorndene SA, Kingsley Publications.

Schreier, D. (2008) St Helenian English: Origins, Evolution and Variation, Amsterdam and Philadelphia, John Benjamins.

Schreier, D., Trudgill, P., Schneider, E.W. \& Williams, J.P. (eds.) (2010) The Lesser-Known Varieties of English: An Introduction, Cambridge, Cambridge University Press. 
J. Nash

Spriggs, M. (2008) 'Are islands islands? Some thoughts on the history of chalk and cheese' in G. Clark, F. Leach and S. O'Connor (eds.), Islands of Inquiry: Colonization, seafaring and the archaeology of maritime landscapes, Canberra, ANU E-Press, pp. 211-226.

Sutton, P. (1995) Country: Aboriginal Boundaries and Land Ownership in Australia, Aboriginal History Monograph No. 3, Canberra, Aboriginal History Inc.

Tent, J. and Slayter, H. (2009) 'Naming Places on the 'Southland': European Placenaming Practices from 1606 to 1803', Australian Historical Studies, Vol. 40, No. 1, pp. 5-31.

Walsh, M. (2002) 'Transparency versus Opacity in Aboriginal Placenames' in L. Hercus, F. Hodges and J. Simpson (eds.) The Land is a Map: Placenames of Indigenous Origin in Australia, Canberra, Pandanus, pp. 43-49. 